\title{
Soil under dead or live organic matter systems: Effect of European shag (Phalacrocorax aristotelis L.) nesting on soil nematodes and nutrient mineralization
}

\author{
Manuel Aira*, Jorge Domínguez \\ Grupo de Ecoloxía Animal (GEA), Facultade de Ciencias, Universidad de Vigo, Vigo E-36310, España
}

\section{ARTICLE INFO}

Article history:

Received October 24, 2019

Revised January 14, 2020

Accepted January 30, 2020

\section{Keywords:}

$\mathrm{C}$ and $\mathrm{N}$ mineralization

Decomposer food web

Nematode trophic structure

Microbial biomass

\begin{abstract}
A B S T R A C T
Here we studied whether soil systems differ if they are under the influence of live (plants) or dead organic matter systems (nest) in terms of $\mathrm{C}$ and $\mathrm{N}$ mineralization, microbiological characteristics and nematode trophic group structure. We analyzed physicochemical and microbiological properties of soils inside and outside nests of the European shag (Phalacrocorax aristotelis L.) on the Cíes Islands (NW Spain). We sampled fresh soil below dead (nests) and live organic matter (plants) (paired samples, $n=7$ ). Soil of nests had lower organic matter and higher electric conductivity and dissolved organic $\mathrm{C}$ and extractable $\mathrm{N}$ contents than the soil of plants. Microbial biomass and activity were greater in soil of nests than in soil of plants. The abundance of nematode trophic groups (bacterivores, fungivores, omnivores and herbivores) differred between soils of nests and plants, and the soil of plants supported a more abundant and diverse nematode community. The present results points to that source of organic matter promote differences in the decomposer community, being more efficient in soil of nests because $\mathrm{C}$ mineralization is greater. Further, this occurred independently of the complexity of the systems, higher in the soil of plants with more groups of nematodes.
\end{abstract}

(c) Higher Education Press 2020

\section{Introduction}

Islands have a significant value in the study of ecology and evolution and their particular characteristics (small isolated areas, simple biological communities, defined boundaries with surrounding ecosystems) make them suitable places for scientific research (Denslow, 2001). However, to our knowl-

\footnotetext{
* Corresponding author

E-mail address: aira@uvigo.es (M. Aira)
}

edge the effect of seabirds on island soils has been investigated mainly for burrowing seabirds (Mulder and Keall, 2001; Bancroft et al., 2005; Fukami et al., 2006; Harrow et al., 2006), but there are no reports of work on the effect of above-ground nesting birds.

Shags can breed in natural cavities under fallen rocks, on open ledges on steep cliffs, or in cavities in the soil (Velando and Freire, 2001, 2003) and their nests are usually composed of vegetation (Angelica pachycarpa, Festuca sp. and Urtica sp.) and unidentified materials (Velando, 1997). The percentage occupation of nests between years is around $75 \%$, and 
the nests are usually occupied by the same individuals (Velando, 1997), which mean that there is almost a continuous supply of resources such as carrion, feathers and faeces. In addition, the soil under nests is protected against erosion by their position into rock cavities. In contrast, outside the nests the plant cover is a key factor in improving soil quality, as it protects the soil from erosion and also it provides organic carbon as root exudates and dead tissues to microorganisms (Balloni and Favilli, 1987; Brockway et al., 1998). These different sources of organic matter may strongly affect soil physicochemical and biological properties. Thus, nutrient incomes in soil of nest are shag derived and complex, ranging from faeces to feathers. Soil communities must therefore metabolize them to make available, as in other decomposing systems (Bardgett and Wardle, 2010). Further, during breeding, inputs from shag activities are continuous and should support higher soil microbial populations. On the other hand, inputs in soil below plants are mainly those derived as plant root exudates, which may be quickly taken by microorganisms. Moreover, and oppositely to shag inputs, plants also exert rigorous control over their root exudates (Kiers et al., 2011), which should limit the soil microbial populations (Bardgett and Wardle, 2011). Living plants should promote the presence of herbivorous and fungivorous nematodes, the latter being grazers of plant mycorrhiza.

The aim of the present study was to study the effects of live (plants) or dead organic matter systems (bird nests) on C and $\mathrm{N}$ mineralization, microbiological characteristics and the composition of nematode communities (trophic groups). For this reason, we analyzed these properties of soils under live (plants) or dead organic matter (nests of the European shag on the Cíes Islands). Differences in the source of organic matter should promote differences in the soil nutrient pools and the soil biota community (microorganisms and nematodes). Thus, due to expected higher $\mathrm{N}$ and $\mathrm{C}$ contents of soils of nest we should expect higher microbial biomass and activity, and a nematode trophic composition dominated by bacterivore nematodes.

\section{Material and methods}

\subsection{Site description}

The Cíes Islands are part of the Atlantic Islands National Park (Galicia, NW Spain). Cliffs on the Cíes Islands consist of steep slopes with a few areas of vegetation established on a shallow soil. In the steepest and highest areas the soil is a leptosol which is subjected to constant renewal processes. In other areas of the cliffs with a less steep, the soil is a typical regosol, characterized by a clear A horizon of variable depth (Foth and Turk, 1981). These soils are subjected to strong seasonal dynamics as the cliffs on the Cies Islands face west and therefore receive most of the incoming rainfall, which strongly affects the scarce and weak vegetation cover. Main plant species inhabiting cliffs are Crithmum maritimum, Calendula suffruticosa subs. algarbiensis, Armeria pubigera, Angelica pachicarpa, and Ulex europaeus.

\subsection{Experimental design}

Sampling was carried out on cliffs in the west of Faro, one of the three islands of the Cies Islands $\left(42^{\circ} 12^{\prime} \mathrm{N}, 12^{\circ} 03^{\prime} \mathrm{W}\right.$; see Velando et al. (2005) for a detailed description of the Cíes Islands). The European shag ( $P$. aristotelis) colony on the Cíes Islands (NW Spain) accounts for approximately $70 \%$ of the Iberian population and $3 \%$ of the world population (Velando et al., 2005). Nests were sampled in the $14^{\text {th }}$ of May (2002), that is the middle of the breeding season for European shags on the Islands, chicks usually hatch in early April and fledge in late June (Velando, 1997). Sampling time was chosen to coincide with the maximum organic inputs from shags due to nest building and subsequent breeding. We chose nests in natural cavities under fallen rocks because they are preferred by shags and because they are protected against erosion, and reoccupied over several years (Velando and Freire, 2001, 2003). We collected pairs of soil samples (n $=7$ ) below dead and live organic matter (plant material), (i.e., nest site and below plant cover respectively), hereafter soil of nests and soil of plants (Fig. 1). Soil of nests was sampled within the natural cavity and soil of plants was sampled out of the rock cavity $2 \mathrm{~m}$ apart from the nest and avoiding nest entrance (Fig. 1). Samples were taken with a PCV corer of $5 \mathrm{~cm}$ diameter to a depth of $5 \mathrm{~cm}$. In each pair of soil of nests and plants we collected six samples for both soil inside and outside the nests, to make a composite sample. No plant roots were observed in soil of nests.

\subsection{Analytical procedures}

Samples were sieved $(2 \mathrm{~mm})$ before to analyses. Samples were dried at $105^{\circ} \mathrm{C}$ for $24 \mathrm{~h}$, to determine the moisture content, and heated at $550^{\circ} \mathrm{C}$ for $4 \mathrm{~h}$ to determine the organic matter content. The $\mathrm{pH}$ and electric conductivity were recorded in a suspension of the samples in distilled water 1:20 (w/v). Ammonium- $\mathrm{N}\left(\mathrm{NH}_{4}{ }^{+}-\mathrm{N}\right)$, nitrate- $\mathrm{N}\left(\mathrm{NO}_{3}{ }^{-} \mathrm{-}\right)$ and total extractable $\mathrm{N}$ were determined in $0.5 \mathrm{M} \mathrm{K}_{2} \mathrm{SO}_{4}$ extracts $(1: 5 \mathrm{w} / \mathrm{v})$ by a modified indophenol blue technique and alkaline persulfate oxidation respectively (Cabrera and Beare, 1993; Sims et al., 1995). Dissolved organic C (DOC) in the samples was determined colorimetrically after moist digestion $\left(\mathrm{K}_{2} \mathrm{Cr}_{2} \mathrm{O}_{7}\right.$ and $\left.\mathrm{H}_{2} \mathrm{SO}_{4}\right)$ of aliquots of $0.5 \mathrm{M} \mathrm{K}_{2} \mathrm{SO}_{4}$ extracts of the samples. The absorbance of all samples was read with a Bio-Rad Microplate Reader 550.

Microbial biomass-C was analyzed by the chloroform fumigation-extraction method (Vance et al., 1987) in $0.5 \mathrm{M}$ $\mathrm{K}_{2} \mathrm{SO}_{4}$ extracts of the samples, and using a extract efficiency factor for microbial $C\left(k_{c}=2.64\right)$. Microbial activity was assessed by measuring $\mathrm{CO}_{2}$ evolution from samples after $6 \mathrm{~h}$ incubation. The evolved $\mathrm{CO}_{2}$ was trapped in $0.02 \mathrm{M} \mathrm{NaOH}$ and then measured by titration with $\mathrm{HCl}$ to a phenolphthalein endpoint, after adding excess $\mathrm{BaCl}_{2}$ (Anderson, 1982). 

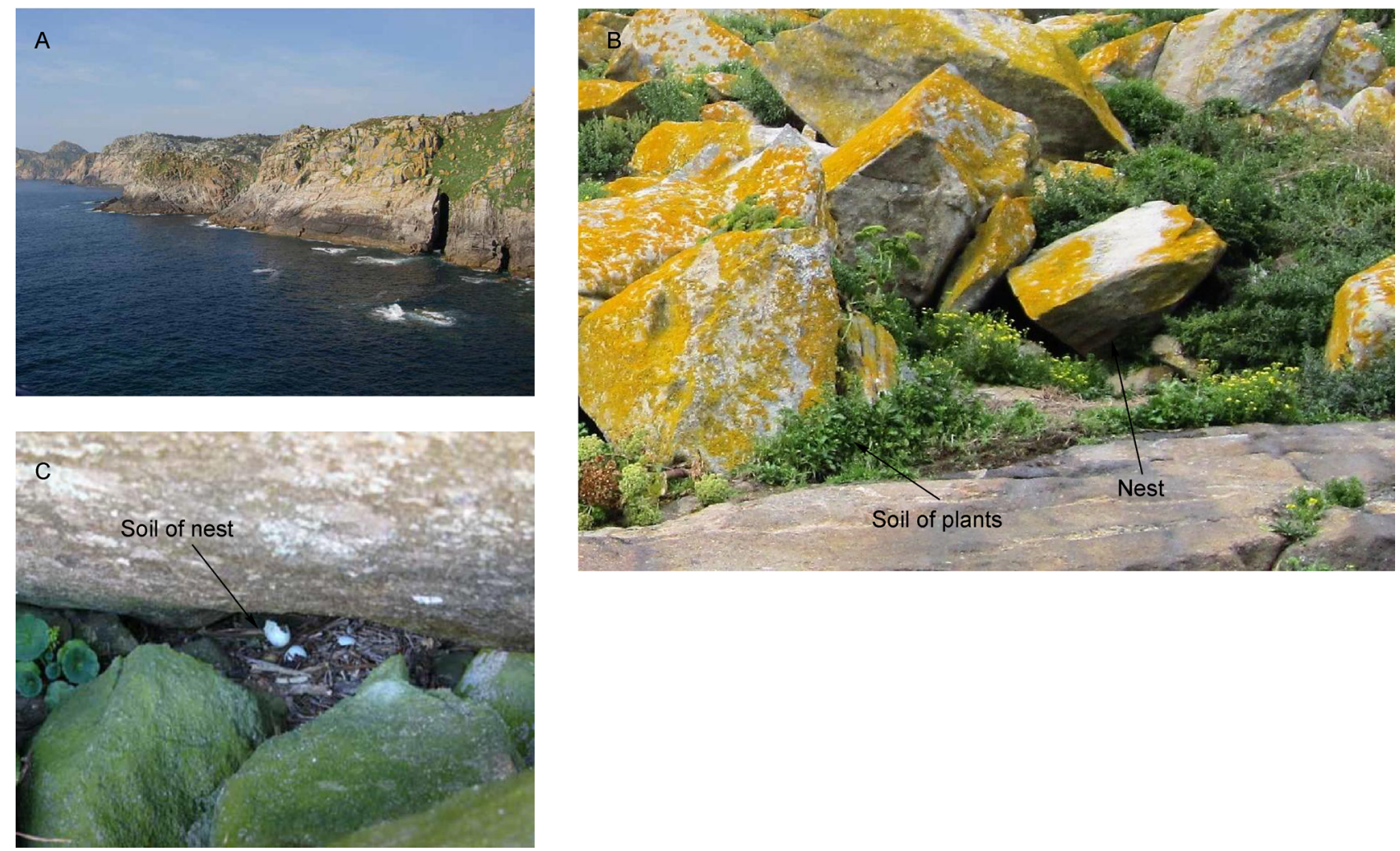

Fig. 1 Experimental sampling design. (A) Cliffs in the west of Faro island at Cies Islands (NW Spain), (B) detail of nestling site showing natural cavities surrounding by plants, and (C) close-up of a nest of shag within a cavity. We collected pairs of composite samples $(n=7)$ in soil of nest and plants (i.e. nest site and below plant cover respectively).

Nematodes were extracted from $20 \mathrm{~g}$ of soil (fresh weight) with modified Baermann funnels, counted live at a magnification of $\times 100$ under a dissecting microscope and sorted into different trophic groups (bacterivores, fungivores, omnivores and herbivores) by oesophageal morphology (Parmelee and Alston, 1986).

\subsection{Statistical analysis}

The data were analyzed by fitting generalized linear models (GLM) to the data (McCullagh and Nelder, 1989). The error distribution and link function were chosen according to presumed error in the data, in order to reduce the deviance in the model (Herrera, 2000). All statistical analyses were performed using R 2.7.2 (2008).

\section{Results}

The moisture content of soil was high and did not differ statistically between samples of soil of nests and soil of plants $(40 \pm 5 \%)$; however, the organic matter content of soil of plants $(36 \pm 2 \%)$ was 1.9 times higher than in soil of nests $(19 \pm 3 \%$; GLM, $\left.F_{1,12}=19.90, P=0.0007\right)$. Both soils were characterized by an acid $\mathrm{pH}$, which was lower in soil of plants $(5.4 \pm 0.1)$ than soil of nests $\left(6.4 \pm 0.4 ; G L M, F_{1,12}=4.70, P=0.05\right)$. Electric conductivity was 12 times higher in soil of nests $(1.2 \pm$ $0.4)$ than soil of plants $\left(0.1 \pm 0.1 ; G L M, F_{1,12}=7.01, P=0.02\right)$.
The inorganic extractable $\mathrm{N}$ was 3 times higher in soil of nests (Fig. 2A; GLM, $F_{1,12}=5.97, P=0.03$ ), whereas, pools of dissolved organic carbon were significantly higher (GLM, $F_{1,12}$ $=7.56, P=0.05$ ) in soil of nests than in soil of plants (Fig. $2 \mathrm{~B}$ ). Microbial biomass was significantly higher in soil of nests than in soil of plants (Fig. 3A; GLM, $F_{1,12}=5.39, P=0.03$ ), as well as microbial activity (Fig. 3B; GLM, $\mathrm{F}_{1,12}=9.61, P=0.009$ ).

Nematodes were more abundant in soil of plants $(125 \pm 45$ nematodes $\left.\mathrm{g}^{-1} \mathrm{dw}\right)$ than in soil of nests $(110 \pm 57$ nematodes $\left.\mathrm{g}^{-1} \mathrm{dw} ; \mathrm{GLM}, \mathrm{F}_{1,12}=6.43, P=0.01\right)$. Nematode trophic structure differed between the two soils with increased numbers of bacterivorous (Fig.4A; GLM, $F_{1,12}=3.98, P=$ 0.04), fungivorous (Fig. 4D; GLM, $F_{1,12}=26.88, P<0.0001$ ) and herbivorous nematodes (Fig. 4B; GLM, $F_{1,12}=5.54, P=$ 0.01 ) in soil of plants. Conversely, omnivorous nematodes showed a reversed trend with slight more nematodes in soil of nests (Fig. 4C; GLM, $\mathrm{F}_{1,12}=1.27, P=0.25$ ).

\section{Discussion}

We found that both microbial biomass and activity were greater in soil of nests, thus partially confirming the data of Fukami et al. (2006), which found high basal respiration rates in seabird nest. The authors attributed the lack of response found in microorganisms, primary consumers, to the increase in secondary consumers (enchytraeids, microbe-feeding 

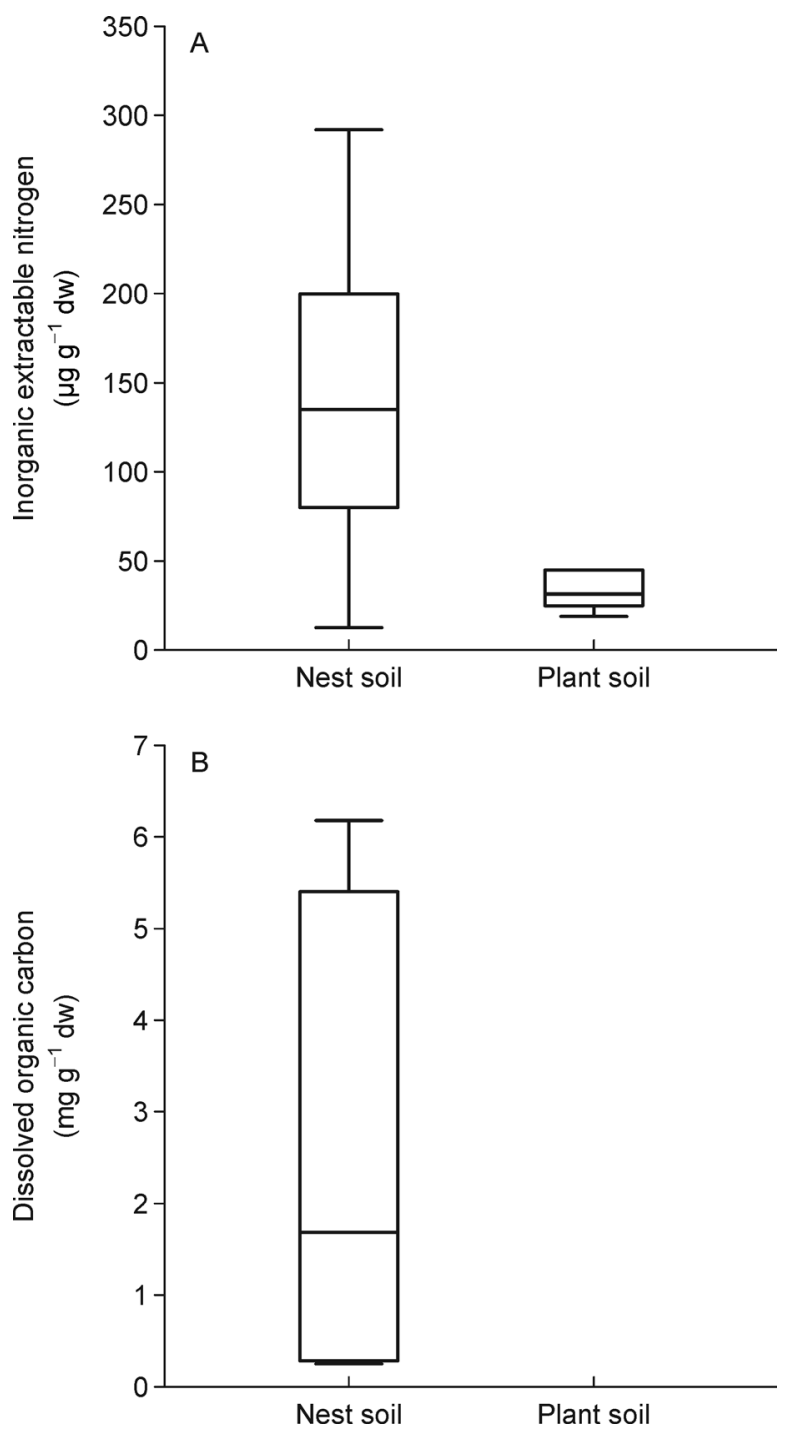

Fig. $2 \mathrm{~N}$ and $\mathrm{C}$ nutrient pools in soil of nest and plants (dead and live organic matter sources respectively), (A) inorganic extractable nitrogen, and (B) dissolved organic $C$ (box plots, paired samples, $n=7$ ).

nematodes, collembolans and rotifers) due to seabird activities non affected by a rat invasion. However, we observed a parallel increase in the microbe-feeding nematodes between soil of nests and plants. Since microbial activity can be stimulated by the addition of labile $C$ to soils (Mikola and Setälä, 1998; Joergensen and Scheu, 1999), the increase in microbial activity in the soil of nests may be due to the high contents of dissolved organic carbon in soils of nests, because these compounds are limiting factors for microbial metabolism (Schmidt, 2000; Ruess et al., 2001).

We found marked differences in inorganic $\mathrm{N}$ pools, which contradicts the data by Hobara et al. (2005) in soil affected or unaffected by shags ( $P$. carbo), but not those by Ligeza and Smal (2003) who found higher inorganic $N$ contents in soils affected by shags ( $P$. carbo sinensis) than in control soils. It is
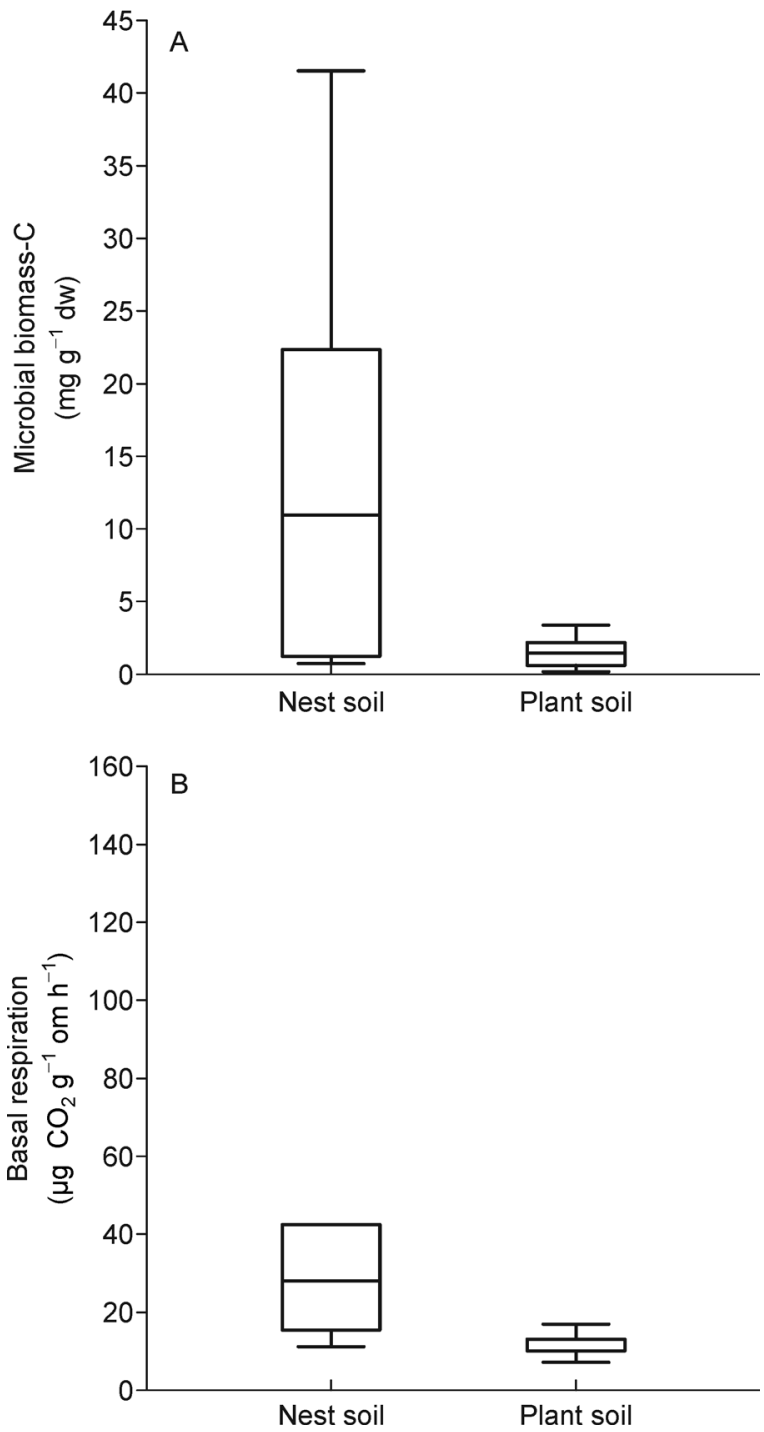

Fig. 3 Soil microbial biomass and activity in soil of nest and plants (dead and live organic matter sources respectively), (A) microbial biomass-C, and (B) basal respiration (box plots, paired samples, $n=7$ ).

important to underline that European shags usually excrete the guano out of the nest opening (Velando, 1997), whereas gulls excrete it all over the colony. Soil moisture did not differed between soils of nests and plants, thus contradicting changes in soil moisture found in desert islands of Gulf of California and in Australian islands (Bancroft et al., 2005; Wait et al., 2005); thus, probably depends on the fact that the weather in Cíes Islands is temperate and rainy. Electric conductivity was consistently higher in soil of nests, and this was probably responsible for the $\mathrm{pH}$ value of soils of nests. Several works studied the effect of guano on soil $\mathrm{pH}$ revealing no consistent effects, i.e. increases or decreases of $\mathrm{pH}$ (reviewed in Wait et al., 2005). Long-term guano deposition is associated with increased contents of soil $\mathrm{N}$ and $\mathrm{P}$ and decreased $\mathrm{pH}$ (Wait et al., 2005), therefore our results suggest 

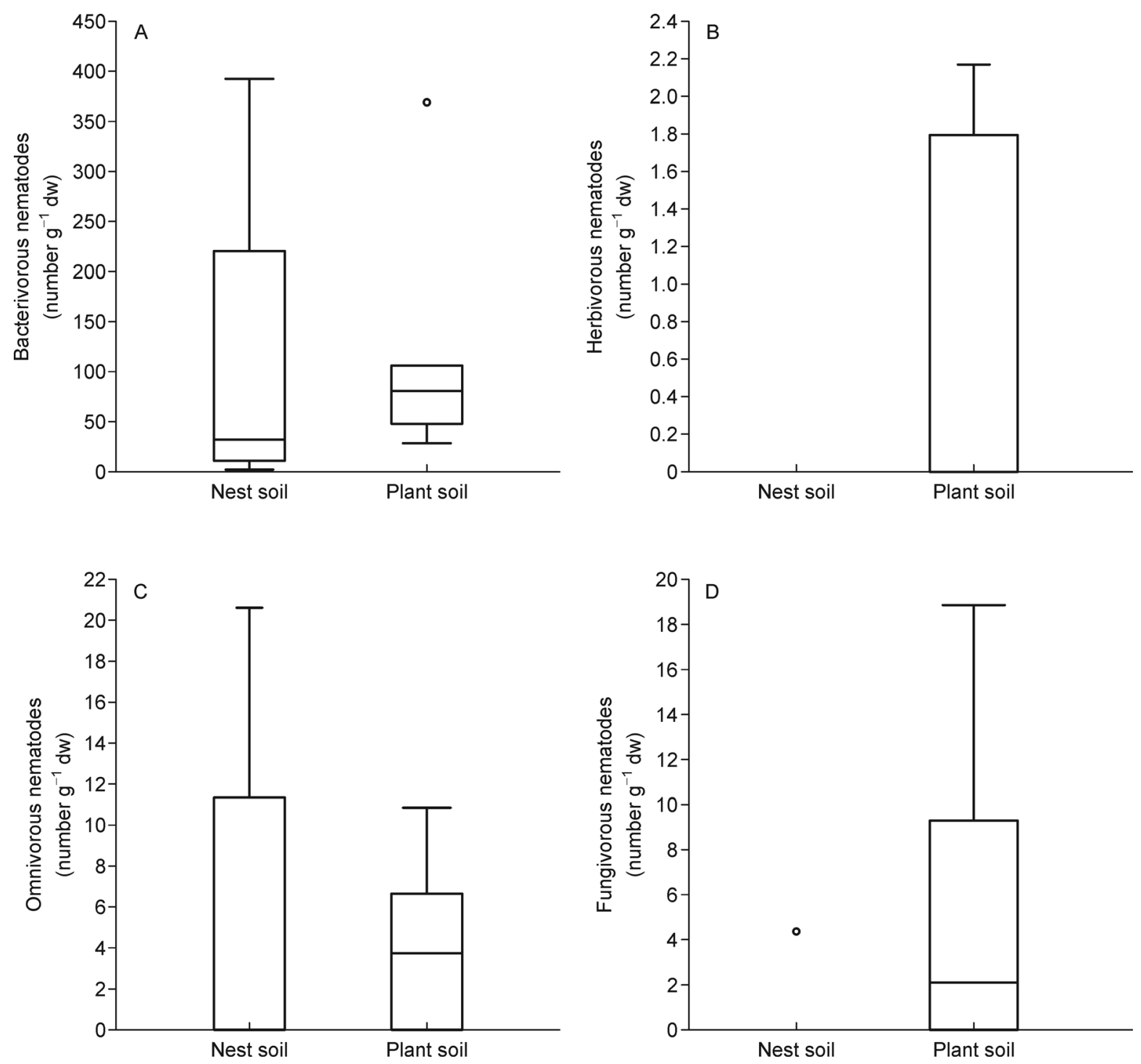

Fig. 4 Nematode trophic structure of soil of nest and plants (dead and live organic matter sources respectively), (A) bacterivorous, (B) herbivorous, (C) omnivorous, and (D) fungivorous nematodes (box plots, paired samples $n=7$ ). All data are expressed in individual numbers $\mathrm{g}^{-1} \mathrm{dw}$

that guano deposition outside the nests in the colony studied should be low, or there is a quick turnover of nutrient guano derived due to growth of vegetation and rain.

Nematodes play an important role in soil ecosystems because they mobilize and mineralize microbial-fixed nutrients (Ingham et al., 1985; Neher, 2001). Bacterivorous nematodes predominated in the nematode populations in soil of nests and plants, which agree with findings of Fukami et al. (2006). Bacterivorous nematodes and protozoa are the main consumers of bacteria in soils (Coûteaux and Darbyshire, 1998), and changes in their populations occur in response to changes in soil bacterial numbers (Venette and Ferris, 1998; Zelenev et al., 2004). According to this, we found differences in numbers of bacterivorous nematodes in soil of nests and plants, matching with the findings on microbial biomass. The composition of nematode communities in soils of nests and plants clearly differed, with higher number of bacterivorous in soil of nest, which had not fungivorous and herbivorous nematodes. This indicates a more complex trophic structure in the nematode community in soil of plants. This may be due to the presence of vegetation and plant-soil feedbacks, which increase nutrient variety and soil microbial diversity (Klironomos, 2002; Reynolds et al., 2003).

\section{Conclusions}

It is generally assumed that there are two kinds of food webs in decomposer ecosystems, which are dominated by either 
bacteria or fungi (Beare et al., 1992; Moore, 1994). Differences in rates of decomposition, loss of organic matter and nutrient mineralization between systems dominated by either bacteria or fungi are due to the differences in carbon assimilation efficiency and turnover rates (Adu and Oades, 1978). Both soil below nest and plants were dominated by bacteria (as indirectly showed by bacterivorous and fungivorous nematodes). The main differences in the two parts of the soil system studied were that nutrient income in soil below nests only comes as a by-product of shag living whereas in soil below plants this is actively controlled by plants in form of root exudates. Thus, incomes derived from shags, which are more complex ranging from uric acid to feathers, must be decomposed whereas root exudates are readily taken by microorganisms. This difference may be the responsible of higher microbial loads and respiration rates found in soil of nest, because shags continuously inputs heavily contrast with the active control that plants have on the amount of exudates they release (Kiers et al., 2011). On the other hand, living plants favoured the existence of herbivore nematodes and fungivorous nematodes, which may predate on plant mycorrhiza. The present results point to that source of organic matter promote differences in the decomposer community, being more efficient in soil below nests because $\mathrm{C}$ mineralization is greater. Further, this occurred independently of the complexity of the systems, higher in the soil below plants with more trophic groups of nematodes.

\section{Acknowledgements}

This study was supported by the Spanish Ministerio de Economía y Competitividad (AGL2017-86813-R) and the Xunta de Galicia (ED431B 2019/38).

\section{References}

Anderson, J.P.E., 1982. Soil respiration, in: Page, A.L., Miller, R.H., (Eds.), Methods of Soil Analysis, Part 2, Chemical and Microbiological Properties 2nd edition. Agronomy mono

graph No. 9, ASA-SSSA, Madison, WI, pp 831-871.

Adu, J.K., Oades, J.M., 1978. Utilization of organic materials in soil aggregates by bacteria and fungi. Soil Biology and Biochemistry 10, 117-122

Balloni, W., Favilli, F., 1987. Effects of agricultural practices on the physical, chemical and biochemical properties of soils. Part I. Effect of some agricultural practices on the biological soil fertility, in: Barth, H., and Hermite, P.L., (Eds.), Scientific Basis for Soil Protection in the European Community, Elsevier, London, pp 161 175.

Bancroft, W.J., Garkaklisb, M.J., Roberts, J.D., 2005. Burrow building in seabird colonies: a soil-forming process in island ecosystems. Pedobiologia 49, 149-165.

Bardgett, R.D., Wardle, D.A., 2010. Aboveground-belowground linkages. Biotic interactions, ecosystem processes, and global change. Oxford University Press
Beare, M.H., Parmelee, R.W., Hendrix, P.F., Cheng, W., 1992. Microbial and faunal interactions and effects on litter nitrogen and decomposition in agroecosystems. Ecological Monographs 62, 569-591.

Brockway, D.G., Outcalt, K.W., Wilkins, R.N., 1998. Restoring longleaf pine wiregrass ecosystems: plant cover, diversity and biomass following long-rate hexazinone application on Florida sandhills. Forest Ecology and Management 103, 159-175.

Cabrera, M.L., Beare, M.H., 1993. Alkaline persulfate oxidation for determining total nitrogen in microbial biomass extracts. Soil Science Society of America Journal 57, 1007-1012.

Coûteaux, M.M., Darbyshire, J.F., 1998. Functional diversity amongst soil protozoa. Applied Soil Ecology 10, 229-237.

Denslow, J., 2001. The ecology of insular biotas. Trends in Ecology and Evolution 16, 423-424.

Foth, H.D., Turk, L.M., 1981. Fundamentos de la ciencia del suelo. Compañía Editorial Continental, México

Fukami, T., Wardle, D.A., Bellingham, P.J., Mulder, C.P.H.,Towns, D. R., Yeates, G.W., Bonner, K.Y., Durrett, M.S., Grant-Hoffman, M. N., Williamson, W.M., 2006. Above- and below-ground impacts of introduced predators in seabird-dominated island ecosystems. Ecology Letters 9, 1299-1307.

Harrow, G., Hawke, D.J., Holdaway, R.N., 2006. Surface soil chemistry at an alpine procellariid breeding colony in New Zealand, and comparison with a lowland site. New Zealand Journal of Zoology 33, 165-174.

Herrera, C.M., 2000. Flower-to-seedling consequences of different pollination regimes in an insect-pollinated shrub. Ecology 81, 1529.

Hobara, S., Koba, K., Osono, T., Tokuchi, N., Ishida, A., Kameda, K., 2005. Nitrogen and phosphorus enrichment and balance in forests colonized by cormorants: Implications of the influence of soil adsorption. Plant and Soil 268, 89-101.

Ingham, R.E., Trofymow, J.A., Ingham, E.R., 1985. Interactions of bacteria, fungi, and their nematode grazers: effects on nutrient cycling and plant growth. Ecological Monographs 55, 119-140.

Joergensen, R.G., Scheu, S., 1999. Response of soil microorganisms to the addition of carbon, nitrogen and phosphorus in a forest rendzina. Soil Biology and Biochemistry 31, 859-866.

Kiers, E.T., Duhamel, M., Beesetty, Y., Mensah, J.A., Franken, O., Verbruggen, E., Fellbaum, C.R., Kowalchuk, G.A., Hart, M.M., Bago, A., Palmer, T.M., West, S.A., Vandenkoornhuyse, P., Jansa, J., Bückin, H., 2011. Reciprocal rewards stabilize cooperation in the mycorrhizal symbiosis. Science 333, 880-882.

Klironomos, J.N., 2002. Feedback with soil biota contributes to plant rarity and invasiveness in communities. Nature 417, 67-70.

Ligeza, S., Smal, H., 2003. Accumulation of nutrients in soils affected by perennial colonies of piscivorous birds with reference to biogeochemical cycles of elements. Chemosphere 52, 595-602.

McCullagh, P., Nelder, J.A., 1989. Generalized linear models. Chapman and Hall, London

Mikola, J., Setälä, H., 1998. Productivity and trophic-level biomasses in a microbial-based soil food web. Oikos 82, 158-168.

Moore, J.C., 1994. Impact of agricultural practices on soil food web structure: theory and application. Agriculture Ecosystems and 
Environment 51, 239-247.

Mulder, C.P.H., Keall, S.N., 2001. Burrowing seabirds and reptiles: impacts on seeds, seedlings and soils in an island forest in New Zealand. Oecologia 127, 350-360.

Neher, D.A., 2001. Role of nematodes in soil health and their use as indicators. Journal of Nematology 33, 161-168.

Parmelee, R.W., Alston, D.G., 1986. Nematode trophic structure in conventional and no-tillage agroecosystems. Journal of Nematology 18, 403-407.

Reynolds, H.L., Packer, A.L., Bever, J.D., Clay, K., 2003. Grassroots ecology: plant-microbe-soil interactions as drivers of plant community structure and dynamics. Ecology 84, 2281-2291.

Ruess, L., Schmidt, I.K., Michelsen, A., Jonasson, S., 2001. Manipulations of a microbial based soil food web at two arctic sites: evidence of species redundancy among the nematode fauna. Applied Soil Ecology 17, 19-30.

Schmidt, I.K., Ruess, L., Baath, E., Michelsen, A., Ekelund, F., Jonasson, S., 2000. Long-term manipulation of the microbes and microfauna of two subarctic heaths by addition of fungicide bactericide carbon and fertilizer. Soil Biology and Biochemistry 32, 707-720.

Sims, G.K., Ellsworth, T.R., Mulvaney, R.L., 1995. Microscale determination of inorganic nitrogen in water and soil extracts. Communications in Soil Science and Plant Analysis 26, 303-316. Vance, E.D., Brookes, P.C., Jenkinson, D.S., 1987. An extraction method for measuring soil microbial biomass C. Soil Biology and Biochemistry 19, 703-707.

Velando, A., 1997. Ecología y comportamiento del cormorán moñudo (Phalacrocórax aristotelis L.) en las Islas Cíes y Ons. Doctoral Thesis, Universidad de Vigo

Velando, A., Freire, J., 2001. Can the central-periphery distribution become general in seabird colonies? Nest spatial pattern in the European Shag. Condor 103, 544-554.

Velando, A., Freire, J., 2003. Nest-site characteristics, occupation and breeding success in the European shag. Waterbirds 26, 473-483.

Velando, A., Munilla, I., Leyenda, P.M., 2005. Short-term indirect effects of the 'Prestige' oil spill on European shags: changes in availability of prey. Marine Ecology Progress Series 302, 263-274.

Venette, R.C., Ferris, H., 1998. Influence of bacterial type and density on population growth of bacterial-feeding nematodes. Soil Biology and Biochemistry 30, 949-960.

Wait, D.T., Aubrey, D.P., Anderson, W.P., 2005. Seabird guano influences on desert islands: soil chemistry and herbaceous species richness and productivity. Journal of Arid Environments 60, 681-695.

Zelenev, V.V., Berkelmans, R., van Bruggen, A.H.C., Bongers, T., Semenov, A.M., 2004. Daily changes in bacterial-feeding nematode populations oscillate with similar periods as bacterial populations after a nutrient impulse in soil. Applied Soil Ecology 26, 93-106. 